\title{
Analisis Pendapatan Usahatani Sawi Manis di Kelurahan Oelami, Kecamatan Bikomi Selatan, Kabupaten Timor Tengah Utara
}

\author{
Emanuel Opat ${ }^{\mathrm{a}}$, dan Adeline Norawati Hutapea ${ }^{\mathrm{b}}$ \\ ${ }^{a}$ Fakultas Pertanian, Universitas Timor, Kefamenanu, TTU - NTT, Indonesia. \\ ${ }^{b}$ Fakultas Pertanian, Universitas Timor, Kefamenanu, TTU - NTT, Indonesia.
}

\section{Article Info}

Article history:

Received 8 April 2017

Received in revised form 20 Mei 2017

\section{Keywords:}

Analisis Usahatani

Biaya

Penerimaan

Pendapatan

Sawi Manis
Accepted 7 Juni 2017

\begin{abstract}
Abstrak
Masyarakat Kelurahan Oelami yang berada di Kecamatan Bikomi Selatan pada umumnya menggantungkan hidup mereka pada usahatan sayuran daun seperti sawi, kangkung, bayam, dan lain-lain. Penelitian ini bertujuan untuk mengetahui 1) gambaran usahatani sawi manis; 2) pendapatan yang diperoleh dari usahatani sawi manis; dan 3) keuntungan relatif yang diperoleh dari usahatani sawi manis di kelurahan Oelami, Kecamatan Bikomi Selatan. Penelitian dilaksanakan di Kelurahan Oelami, Kecamatan Bikomi Selatan, Kabupaten TTU, pada Bulan Mei sampai Agustus 2016. Populasi dalam penelitian ini adalah semua petani sawi manis yang berjumlah 50 KK dengan 33 orang diambil sebagai responden. Data yang digunakan dalam penelitian ini adalah data primer yang diperoleh dengan teknik wawancara langsung dengan responden atau petani dan data sekunder diperoleh dari instansi terkait. Analisis data yang digunakan adalah analisis deskriptif kualitatif, analisis pendapatan dan analisis R/C Rasio. Hasil penelitian menunjukkan usahatani sawi manis yang dilakukan petan di Kelurahan Oelami menggunakan lahan sendiri. Tahap kegiatan usahatani sayur sawi manis dimulai dari pengolahan lahan, persemaian, penanaman, penyulaman, pemeliharaan, pengendalian hama, pemupukan, panen dan pasca panen. Biaya yang di keluarkan dalam kegiatan usahatani sayur sawi manis adalah biaya variabel dan biaya tetap dengan rata-rata total biaya sebesar Rp 962.255,55 dan total biaya sebesar Rp 31.754.433, sedangkan penerimaan dari petani sayur manis dalam satu kali musim tanam rata-rata Rp. 2.754.090 dan total penerimaan sebesar Rp. 90.885.000, sehingga petani sayur sawi manis memperoleh pendapatan rata-rata sebesar Rp. 1.791.835,354 dengan total pendapatan sebesar Rp. 59.130.566. Rata-rata keuntungan relatif dalam kegiatan usahatani sayur sawi manis yang diperoleh petani sebesar 2,86 artinya kegiatan usahatani sayur sawi manis yang dilakukan oleh petani di kelurahan Oelami menguntungkan secara ekonomis. (O2017 dipublikasikan oleh Agrimor.
\end{abstract}

\section{Pendahuluan}

Sawi manis merupakan jenis komoditi hortikultura yang paling banyak diusahakan oleh masyarakat jika dibandingkan dengan jenis komoditi lainya karena mempunyai umur panen yang relatif pendek sehingga cepat dipanen, teknologi yang digunakan untuk mengusahakan sawi sangat sederhana dan hasi produksi sawi dapat terserap di pasar karena merupakan salah satu komponen susunan menu keluarga yang tidak dapat ditinggalkan, itulah sebabnya petan pengusaha sayuran pada umumnya lebih terdorong sehingga menjatuhkan pilihan untuk mengusahakan sayuran sawi.

Sawi merupakan jenis tanaman sayuran daun yang memiliki nilai ekonomis tinggi. Selain itu, tanaman sawi juga mengandung mineral, vitamin, protein dan kalori (Haryanto et al., 2007). Menurut Nusifera (2004), sawi mengandung serat, vitamin $\mathrm{A}$, vitamin $\mathrm{B}$, vitamin $\mathrm{B} 2$, vitamin $\mathrm{B} 6$, vitamin $\mathrm{C}$, kalium, fosfor, tembaga, magnesium, zat besi dan protein.

Kecamatan Bikomi Selatan, yang berada di Kabupaten Timor Tengah Utara (TTU) tidak hanya dikenal sebagai Kecamatan yang memiliki berbagai macam industri Kecil menengah namun, dikenal juga sebagai Kecamatan penghasil sawi manis dan penyuplai sawi manis untuk pasaran seperti Pasar Baru Kefamenanu bahkan hingga dipasarkan ke Kabupaten Timor Tengah Selatan (TTS).

Berdasarkan data yang diperoleh dari Badan Pusat Statistik produksi sawi manis pada Kecamatan Bikomi Selatan selama 5 tahun terakhir berfluktuasi, tahun 2011 hasil produksi sayur sawi manis yaitu 14 ton dengan luas lahan panen sebesar 4,5 ha, tahun 2012 produksi sayur sawi manis sebesar 13 ton dengan luas lahan panen sebesar 3,8 ha, tahun 2014 produksi sayur sawi manis sebesar 11 ton dengan luas lahan panen sebesar 2,8 ha, dan tahun 2015 produksi sayur sawi manis sebesar 14 ton dengan luas lahan panen sebesar 4,5 ha (BPS Kab. TTU, 2016) dengan berat setiap tanaman menurut Banu et al., (2016) berkisar antara $110-174 \mathrm{~g}$.

Masyarakat Kelurahan Oelami yang berada di Kecamatan Bikomi Selatan pada umumnya menggantungkan hidup mereka pada usahatani sayuran daun seperti sawi, kangkung, bayam, dan lain-lain. Namun berdasarkan hasil survey awal di lokasi penelitian masyarakat kelurahan Oelami dominan mengusahakan sayuran sawi dikarenakan tidak membutuhkan biaya yang besar dalam berusahatani sawi karena benih lebih murah dari sayur lain dan komoditi ini mempunyai umur panen cepat sehingga memberikan input yang besar bag petani. Selain itu usahatani sawi tidak membutuhkan pengetahuan atau pengalaman khusus, hal ini sejalan dengan hasil penelitian Lama \& Kune, (2016) yang memberikan gambaran bahwa faktor pengalaman dan pendidikan tidak memberikan pengaruh yang nyata pada produksi usahatani sawi di kelurahan Bansone, kabupaten TTU. Usboko \& Fallo, (2016) juga menyatakan bahwa faktor pendidikan tidak berpengaruh nyata pada produksi usahatani sawi di kelompok tani Mitra Timor.

Hasil produksi yang diperoleh kebanyakan masyarakat menjual di pasar Baru Kefamenanu, menjual langsung ke konsumen ada juga yang langsung menjual ke pedagang pengecer. Pendapatan dari usahatani sawi selama ini selain digunakan untuk pemenuhan kebutuhan ekonomi keluarga, juga digunakan untuk menyekolahkan anak mereka hingga jenjang pendidikan tinggi, pendapatan sebagian digunakan sebagai modal baik untuk mengembangkan usahatani sawi dan juga digunakan untuk berusahatani lainya. Mesk berkontribusi cukup besar pada perekonomian, tetapi petani belum menghitung dan mengetahui secara jelas pendapatan yang diperoleh dari usahatani sawi manis untuk setiap kali produksi. Dengan demikian maka penting untuk melakukan kajian tentang "Analisis Pendapatan Usahatani Sawi Manis di Kelurahan Oelami, Kecamatan Bikomi Selatan, Kabupaten Timor Tengah Utara". Penelitian ini bertujuan untuk mengetahui 1) gambaran usahatani sawi manis; 2) pendapatan yang diperoleh dari usahatani sawi manis; dan 3) keuntungan relatif yang diperoleh dari usahatani sawi manis di kelurahan

\section{Metode}

Penelitian dilaksanakan di Kelurahan Oelami, Kecamatan Bikomi Selatan, Kabupaten TTU, pada Bulan Mei sampai Agustus 2016. Populasi dalam penelitian ini adalah semua petani sawi manis di kelurahan Oelami, Kecamatan Bikomi Selatan yang paling dominan mengusahakan sawi manis sehingga populasi dalam penelitian berjumlah $50 \mathrm{KK}$.

Teknik pengambilan sampel dalam penelitian ini menggunakan teknik simple random sampling yaitu pengambilan sampel secara acak dimana setiap elemen dari populasinya mempunyai peluang yang sama-sama besar untuk terpilih ke dalam sampel. Teknik pengambilan dan penetapan jumlah sampel penelitian dilakukan dengan cara menggunakan rumus slovin sesuai petunjuk Ating \& Sambas, (2006) sehingga jumlah sampel yang digunakan adalah sebanyak 33 responden.

Data yang digunakan dalam penelitian ini adalah data primer yang diperoleh dengan teknik wawancara langsung dengan responden atau petani pengusaha sawi manis di lokasi penelitian berdasarkan daftar pertanyaan yang disiapkan oleh peneliti sedangkan data sekunder diperoleh dari instansi atau lembaga terkait.

Data yang diperoleh dikumpulkan kemudian ditabulasi dan dianalisis berdasarkan tujuan penelitian. Untuk menjawab tujuan pertama yaitu mengetahui gambaran umum produksi sawi manis peneliti menggunakan metode analisis deskriptif kualitatif sesuai petunjuk Sugiyono, (2006). Untuk menjawab tujuan kedua dan ketiga, dilakukan analisis pendapatan dan analisis R/C Rasio sesuai petunjuk Soekartawi, (1995).

\subsection{Gambaran Umum Usahatani Sawi Manis}

Masyarakat Kelurahan Oelami memilih komoditi sawi manis karena Tanaman sawi memiliki umur panen yang cepat, dan tumbuh dengan baik pada musim kemarau, sehingga dapat ditanam sepanjang tahun. Selain itu juga lokasi penelitian memiliki 4 embung sehingga memudahkan petani dalam penyiraman. Berikut ini adalah tahap-tahap budidaya tanaman sawi yang meliputi persiapan dan pengolahan lahan, pemupukan dasar, persemaian, penanaman, penyulaman, pemeliharaan, pengendalian hama, pemupukan, panen dan pasca panen.

a. Pengolahan lahan

Pengolahan lahan dimulai dengan tanah dibalik terlebih dahulu menggunakan linggis dan membuat bedeng berukuran lebar \pm 2 atau 3 meter dengan panjang bedengan disesuaikan dengan ukuran lahan yang dimiliki sedangkan tinggi bedengan mencapai $\pm 20-30 \mathrm{~cm}$.

b. Persemaian

Benih yang sudah dibeli oleh petani kemudian disemaikan pada bedeng yang sudah disiapkan terlebih dahulu dengan ukuran $2 \times 1 \mathrm{~m}$, persemaian dilakukan dengan cara menaburkan benih pada bedengan, benih yang sudah disemaikan diberi perawatan sehingga semua benih bisa berkecambah, proses perkecambahan benih $\pm 3-4$ hari. Setelah bibit sayur sawi yang tumbuh mencapai umur \pm 3 atau 4 minggu atau jumlah helai daun bibit sawi manis berjumlah $4-5$ helai maka bibit siap ditraspalanting atau ditanam.

c. Penanaman

Penanaman dilakukan setelah bibit sawi manis mempunyai 4 sampai 5 helai daun. Sebelum penanaman bedengan disiram terlebih dahulu. Petani membuat lubang tanam pada bedengan dengan jarak $\pm 20 \times 20 \mathrm{~cm}$. sebelum bibit dicabut Oelami, Kecamatan Bikomi Selatan.

\section{Hasil dan Pembahasan}


sebaiknya disiram terlebih dahulu agar akar bibit tidak rusak. Bibit sawi manis ditanam $\pm 2-3$ bibit per lubang, sesudah ditanam bedengan tersebut disiram dengan air secukupnya.

d. Penyulaman

Penyulaman dilakukan oleh masyarakat petani apabila terdapat bibit sawi yang tidak tumbuh. Penyulaman biasanya dilakukan pada saat tanaman masih berumur \pm 1 minggu sehingga waktu panen dapat bersamaan.

e. Pemeliharaan

Pemeliharaan merupakan bagian yang tidak dapat dipisahkan dari suatu usahatani adapun pemeliharaan yang dilakukan oleh petani di Kelurahan Oelami, adalah:

\section{○ Penyiraman}

Penyiraman dilakukan 2 kali dalam sehari yaitu pada pagi hari dan sore hari, untuk lebih memudahkan saat penyiraman masyarakat petani sayur sawi manis di Kelurahan Oelami menggunakan motor air karena keadaan bedengan yang luas.

- Pemupukan

Kegiatan pemupukan dilakukan dengan 2 tahap yaitu pemupukan dasar dan pemupukan lanjutan. Pemupukan dasar dilakukan setelah bedengan dibuat, bedengan didiamkan \pm 3-4 hari agar tanah kering dan dilakukan pemupukan dasar dilakukan dengan cara menghamburkan dedaunan seperti daun gamal di atas bedengan atau kotoran sapi, kuda dan kambing dan kelelawar yang sudah kering di atas bedengan secara merata dan dilakukan penyiraman dengan tujuan agar pupuk kandang yang telah dihamburkan menyatu dengan tanah. Pemupukan lanjutan dilakukan 3 minggu setelah sayur sawi manis ditanam, jenis pupuk yang digunakan adalah jenis pupuk kimia yaitu pupuk Urea, KCL dan pupuk TSP, pemupukan dilakukan dengan cara mencampur ketiga jenis pupuk tersebut dengan tujuan agar reaksinya ke tanaman cepat dan menjadi subur.

- Pengendalian Hama

Hama yang sering menyerang tanaman sayur sawi antara lain ulat grayak, kutu daun. Sedangkan penyakit antara lain karat putih. Untuk mencegah hama dan penyakit tersebut masyarakat petani di kelurahan Oelami menggunakan pestisida Danke, Badik dan Karino. Petani memilih pestisida ini karena tidak menimbulkan risiko terhadap tanaman sawi dan reaksinya sangat cepat dalam mengatasi hama atau penyakit yang menyerang tanaman tersebut.

- Penyiangan

Penyiangan dilakukan dengan pembersihan gulma dan dilakukan secara hati-hati sehingga tidak menginjak tanaman sawi manis tersebut.

f. Panen

Petani melakukan pemanenan setelah tanaman sayur sawi manis berumur 40 sampai 50 hari, panen dilakukan dengan cara mencabut sayur sawi manis dari bedengan dan membersihkan sisa tanah yang masih melekat pada sayur sawi manis dengan cara dipotong pada pangkal batang yang dekat dengan akar. Petani melakukan panen pada saat pagi hari dengan tujuan dijual kepada pedagang pengumpul atau bisa dijual sendiri.

g. Pasca Panen

Pasca panen adalah tahap terakhir dalam kegiatan usahatani, pasca panen bertujuan untuk menjaga kesegaran sawi tersebut dengan cara lakukan percikan air bersih pada bagian daun dan disimpan di tempat yang teduh dan membungkus sayuran tersebut menggunakan daun pisang. sayur sawi manis tersebut diikat menggunakan tali gewang.

\subsection{Analisis Pendapatan Usahatani Sawi Manis.}

Untuk menganalisis besarnya pendapatan yang diperoleh maka akan dijelaskan komponen-komponen yang terkait, di antaranya:

a. Penggunaan Lahan.

Berdasarkan hasil penelitian dapat ketahui bahwa lahan yang digunakan untuk berusahatani sayur sawi manis adalah lahan milik sendiri dengan luasan lahan yang digunakan berkisar antara $9-20$ are, untuk lebih jelas dapat dilihat pada Tabel 1 .

Tabel 1. Kisaran Luas Lahan Untuk Usahatani Sayur Sawi Manis di Kelurahan Oelami, Kecamatan Bikomi Selatan, Kab TTU.

\begin{tabular}{ccc}
\hline $\begin{array}{c}\text { Luas Lahan yang } \\
\text { Diusahakan (Are) }\end{array}$ & $\begin{array}{c}\text { Jumlah Petani } \\
\text { (Orang) }\end{array}$ & Persentase $(\%)$ \\
\hline $9-12$ & 9 & 27 \\
$13-16$ & 19 & 58 \\
$17-20$ & 5 & 15 \\
\hline Jumlah & 33 & 100 \\
\hline
\end{tabular}

Berdasarkan Tabel 1. diketahui bahwa persentase luas lahan usahatani sayur sawi manis tertinggi yakni berkisar antara 13-16 are dengan persentase 58\% sebanyak 19 orang petani, sedangkan luas lahan usahatani sayur sawi manis terendah yakni berkisar antara $17-20$ are dengan persentase $15 \%$ sebanyak 5 orang petani.

\section{b. Tenaga Kerja}

Untuk tenaga kerja di lokasi penelitian berasal dari tenaga kerja dalam keluarga yang merupakan sumbangan dalam keluarga pada produksi secara keseluruhan dan tidak dinilai dengan uang (upah tenaga kerja).

Konsep tenaga kerja menurut Soeharjo \& Patong, (1973) yakni dalam 1 hari seorang tenaga kerja bekerja selama 7 hari jam penuh dan dalam 1 bulan terdapat
25 hari efektif maka dalam satu tahun terdapat 300 hari kerja efektif Berdasarkan konsep tersebut maka potensi tenaga kerja yang tersedia dalam satu bulan yakni $100 \mathrm{HKO}$ dan untuk satu tahun $1200 \mathrm{HKO}$.

Tabel 2. Rata- rata Curahan Tenaga Kerja Berdasarkan Jenis Kegiatan Usahatani Sayur Sawi di Kelurahan Oelami, Kecamatan Bikomi Selatan, Kab TTU.

\begin{tabular}{clc}
\hline No & \multicolumn{1}{c}{ Jenis Kegiatan } & $\begin{array}{c}\text { Rata-rata Curahan } \\
\text { Tenaga Kerja (HKO) }\end{array}$ \\
\hline 1 & Pengolahan Tanah & 8,60 \\
2 & Pemupukan Dasar & 1,53 \\
3 & Persemaian & 0,40 \\
4 & Penanaman & 2,54 \\
5 & Penyulaman & 0,58 \\
6 & Pemeliharaan/Penyiraman & 60,41 \\
7 & Pengendalian & 1,32 \\
8 & Pemupukan & 2,29 \\
9 & Panen & 4,35 \\
10 & Pasca Panen & 2,85 \\
\hline
\end{tabular}

Dari Tabel 2. dapat dijelaskan bahwa rata- rata curahan tenaga kerja tertinggi adalah pada tahapan pemeliharaan atau penyiraman dengan rata- rata curahan tenaga kerja yakni $60,41 \mathrm{HKO}$. Hal ini dikarenakan penyiraman dapat dilakukan setiap hari hingga sayur sawi dipanen dan curahan tenaga kerja terendah terdapat pada tahap usahatani persemaian dan yakni 0,40 HKO. pada tahap ini curahan tenaga kerja sedikit karena persemaian dilakukan pada bedengan yang kecil.

\section{c. Biaya Produksi Usahatani Sawi Manis}

- Biaya Variabel

Biaya variabel merupakan biaya yang harus dikeluarkan terus menerus oleh petani untuk satu kali produksi. Berdasarkan hasil penelitian yang dilakukan di petani sayur sawi manis di Kelurahan Oelami, rata-rata biaya yang dikeluarkan dalam satu kali produksi atau satu kali musim tanam sebesar Rp.675.000

Biaya produksi tersebut terdiri dari beberapa jenis biaya yang dikeluarkan yakni benih dengan rata-rata biaya sebesar Rp.222.272,7 pupuk sebesar Rp.33.939,39, biaya transportasi penjualan sebesar, Rp.18.787,87, biaya Pestisida, Rp.214.393, transportasi pembelian saprodi sebesar, Rp.11.212,121, dan pengeluaran Bensin selama penyiraman sebesar Rp.51.515,15.

Dalam perhitungan biaya variabel ini, biaya tenaga kerja tidak diperhitungkan karena tenaga kerja yang dibutuhkan berasal dari keluarga petani itu sendiri sehingga peneliti hanya menghitung biaya konsumsi yang di keluarkan selama melakukan kegiatan usahatani untuk satu kali produksi atau satu kali musim tanam yang sebesar Rp.122.879.

- Biaya Tetap

Biaya tetap adalah biaya yang dikeluarkan selama proses produksi yang besarnya tidak dipengaruhi oleh banyaknya produksi yang dihasilkan, dinyatakan dalam satuan rupiah. Biaya tetap dalam penelitian ini merupakan biaya penyusutan peralatan. Biaya penyusutan peralatan merupakan pengurangan nilai barang-barang modal karena terpakai dalam proses produksi/karena faktor waktu yang dinyatakan dalam satuan rupiah.

Penyusutan Peralatan yang dihitung dalam penelitian ini meliputi linggis, parang, tajak, ember, motor air, dan selang. Menurut Baridwan, (2008), biaya penyusutan peralatan ini dihitung menggunakan metode garis lurus (straight line method) dengan rumus sebagai berikut: Penyusutan: (Harga Beli - nilai sisa) / umur ekonomis. Berdasarkan perhitungan menggunakan rumus metode garis lurus tersebut di atas memperoleh hasil sebagai berikut: rata-rata biaya yang dikeluarkan petani dalam berusahatani sayur sawi manis di Kelurahan Oelami sebesar Rp 288.316, dari total keseluruhan biaya yang dikeluarkan sebesar Rp 9.514 .433

\section{d. Penerimaan Usahatani.}

Penerimaan merupakan perkalian antara produksi sayur sawi manis dengan harga jual sawi manis per ikat. Berdasarkan hasil penelitian sawi manis yang diusahakan di Kelurahan Oelami produksi sawi manis dalam satu kali musim tanam rata-rata 2754 ikat dengan harga jual per ikat ditingkat petani Rp 1.000.

Berdasarkan hasil penelitian, penerimaan usahatani sawi manis di Kelurahan Oelami dalam satu kali musim tanam sebesar Rp 2.754.090, dan rata-rata 2754 ikat sayur sawi manis dan harga ditingkat petani Rp 1.000 per ikat. Sedangkan total keseluruhan produksi untuk satu kali musim tanam sawi manis sebanyak 90885 ikat dan total penerimaan sebesar Rp. 90.885.000,

\section{e. Pendapatan.}

Pendapatan merupakan hasil penjualan bersih yang diterima oleh petani dalam kegiatan usahatani, pendapatan diperoleh dari selisih antara penerimaan dengan total biaya yang terdiri dari biaya tetap dan biaya variabel. Berdasarkan hasil perhitungan diperoleh total biaya sebesar Rp 31.754.433 dengan rata-rata total biaya sebesar Rp 926.255,55 sedangkan total penerimaan sebesar Rp 90.885.000 dengan rata-rata penerimaan sebesar Rp 2.754.090.

Berdasarkan hasil perhitungan tersebut dapat diketahui total pendapatan petani sayur sawi manis di Kelurahan Oelami dengan menghitung selisih antara penerimaan dengan total biaya sehingga hasil total pendapatan sebesar Rp. 
59.130.566 dengan rata-rata pendapatan petani sawi manis sebesar Rp 1.791.835,55. Untuk lebih jelas dapat dilihat pada Gambar 1.

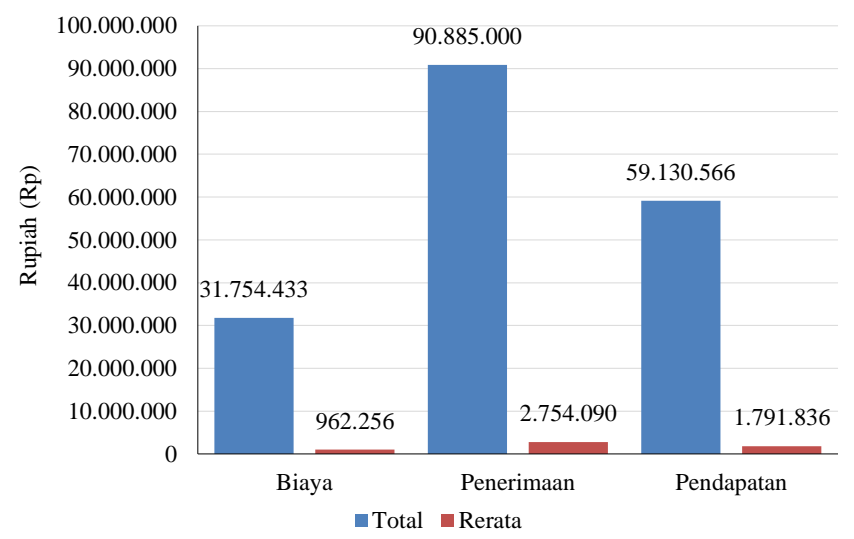

Gambar 1. Total dan Rata-Rata Biaya, Penerimaan dan Pendapatan yang Diperoleh Petani Sayur Sawi Manis di Kelurahan Oelami untuk Satu Kali Musim Tanam.

\subsection{Keuntungan Relatif (R/C Ratio)}

Keuntungan relatif merupakan pembagian antara total penerimaan dengan total biaya selama satu kali produksi sawi manis. Berdasarkan perhitungan R/C Ratio diperoleh total R/C Ratio sebesar 94,65 dengan nilai rata-rata R/C Ratio sebesar 2,86. Nilai ini masih lebih rendah yang diperoleh petani sawi di desa Humusu Oekolo yang menurut Nubatonis, (2016) memperoleh nilai R/C sebesar 3,27 , meski demikian, dari hasil tersebut dapat disimpulkan bahwa usahatani sawi manis di kelurahan Oelami, Kecamatan Bikomi Selatan, berada pada posisi menguntungkan karena nilai yang diperoleh lebih besar dari 1 artinya bahwa setiap pengeluaran 1 rupiah dapat memberikan keuntungan sebesar 2,86.

\section{Simpulan}

Usahatani sawi manis yang dilakukan petani di Kelurahan Oelami menggunakan lahan sendiri. Tahap kegiatan usahatani sayur sawi manis dimulai dari pengolahan lahan, persemaian, penanaman, penyulaman, pemeliharaan, pengendalian hama, pemupukan, panen dan pasca panen. Biaya yang di keluarkan dalam kegiatan usahatani sayur sawi manis adalah biaya variabel dan biaya tetap dengan rata-rata total biaya sebesar Rp 962.255,55 dan total biaya sebesar Rp 31.754.433, sedangkan penerimaan dari petani sayur manis dalam satu kali musim tanam rata-rata Rp. 2.754.090 dan total penerimaan sebesar Rp. 90.885.000, sehingga petani sayur sawi manis memperoleh pendapatan rata-rata sebesar Rp. 1.791.835,354 dengan total pendapatan sebesar Rp. 59.130.566. Rata-rata keuntungan relatif dalam kegiatan usahatani sayur sawi manis yang diperoleh petani sebesar 2,86 artinya kegiatan usahatani sayur sawi manis yang dilakukan oleh petani di kelurahan Oelami menguntungkan secara ekonomis.

\section{Pustaka}

Ating, S. \& Sambas, A.M. 2006. Aplikasi Statistika Dalam Penelitian. Bandung: Penerbit Pustaka Setia.

Banu, H., Taolin, R.I.C.O. \& Lelang, M.A. 2016. Pengaruh Dosis Pupuk Mitra Flora dan Ekstrak Daun Kelor (Moringa oleifera) Terhadap Pertumbuhan dan Hasil Tanaman Sawi (Brassica juncea, L.). Savana Cendana, 1(01): 8 12.

Baridwan, Z. 2008. Sistem Akuntansi Penyusunan Prosedur dan Metode. 5 ed. Yogyakarta: BPPE.

BPS Kab. TTU 2016. Timor Tengah Utara dalam Angka 2015. Kefamenanu: Badan Pusat Statistik Kabupaten TTU.

Haryanto, E., Suhartini, T., Estu, R. \& Sunarjono, H.H. 2007. Sawi \& Selada. Jakarta: Penebar Swadaya.

Lama, M. \& Kune, S.J. 2016. Faktor-Faktor yang Mempengaruhi Produksi Usaha Tani Sayur Sawi di Kelurahan Bensone Kecamatan Kota Kefamenanu Kabupaten Timor Tengah Utara. AGRIMOR, 1(02): 27-29.

Nubatonis, A. 2016. Analisis Pendapatan Usahatani Sawi di Desa Humusu Oekolo Kecamatan Insana Utara Kabupaten Timor Tengah Utara. AGRIMOR, 1(01): 1-2.

Nusifera, S. 2004. Respons tanaman sawi (Brassica juncea L.) terhadap pupuk daun Nutra-Phos N dengan konsentrasi bervariasi. Jurnal Agronomi, 8(1): 27-29.

Soeharjo, A. \& Patong, D. 1973. Sendi-sendi pokok ilmu usahatani. Bogor: Departemen Ilmu Sosial Ekonomi. Fakultas Pertanian, Institut Pertanian Bogor.

Soekartawi 1995. Analisis Usaha Tani. Jakarta: Universitas Indonesia Press.

Sugiyono 2006. Metode Penelitian Kuantitatif, Kualitatif dan $R \& D$. Bandung: Alfabeta.

Usboko, A.M. \& Fallo, Y.M. 2016. Faktor Sosial Ekonomi yang Mempengaruhi Produksi Usahatani Sayuran Sawi di Kelompok Tani Mitra Timor. AGRIMOR, 1(03): 60-62. 